\title{
Consolidated techniques for groups of enterprises with complex structure
}

\author{
Cristina Ciuraru-Andrica, University "Vasile Alecsandri” from Bacau, Romania
}

\begin{abstract}
:
The preparation and disclosure of the financial statements of a group of enterprises involves some consolidation techniques. The Literature presents many techniques, but in practice are used two of them. They will be described first of all in a particular manner and after that in a comparative one. The group of entities can choose one of these techniques, the final result (the consolidated financial statements) being the same, whatever the option.
\end{abstract}

\section{Key words:}

Consolidated financial statements, levels consolidation, direct consolidation

\section{Introduction}

The Romanian explicative dictionary defines technique as an aggregate of proceedings and skills used in a certain activity. For achieve its goals (the content of consolidated financial statements and also the rules for their preparation, approval, audit and disclosure), the consolidated accounting (a department of financial accounting applied in case of groups of enterprises), uses a so-called consolidation technique. According to above technique's definition, the consolidation technique regards an aggregate of empirical proceedings and skills used, especially, for preparation of annual consolidated financial statements, legal.

The Literature ${ }^{1}$ refers to four techniques of consolidation: levels consolidation technique, direct consolidation technique, modular consolidation technique and the technique of consolidation using fluctuations method.

The modular consolidation technique consists in separating the entities' financial statements on module. These will be regrouped later, according to the needs of the group regarding the administration, on different activities, geographic area, production's matters etc.

The technique of consolidation using fluctuations method starts with the previous period's consolidated information and continues with the integration of consolidated flows of the current accounting period, which allows resolving not only the problem of booking them, but also the problem of annual consolidation area.

In our country practice, are used the left techniques: levels consolidation technique and direct consolidation technique, probably as a result of stipulate them in the first rule regarding consolidated financial statements (approved by O.M.F. nr. 772/2.000 recalled by O.M.F.P. nr. 1.752/2.005 also recalled by O.M.F.P. 3.055/2.009).

It is imperative to say that these techniques are not applied to any case of entities group. For a group of enterprises with a dentritic organigram and one level of boundaries between them (fig. no. 1) these techniques are not applicable. Whatever, in

${ }^{1}$ Feleagă N., Ionaşcu I. (1998), Tratat de contabilitate financiară, vol. I-II, Ed. Economicã, București 
practice, such a simple groups do not often exist. Therefore these intervene in case of complex groups (fig. no. 2) made by joining direct and indirect investments with those linear, multiple, circular and mutual.

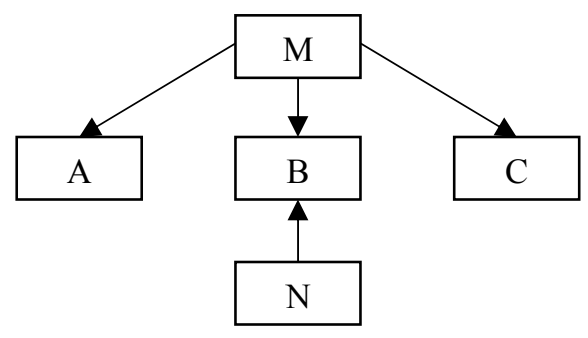

Figure no. 1 Simple group

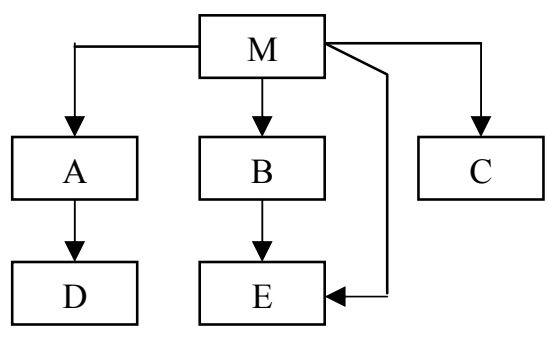

Figure no. 2 Complex group

These consolidation techniques used in the preparation of consolidated financial statements are applied jointly with the consolidation methods scheduled in regulations ${ }^{2}$. Moreover, they lead, in most cases, to a combination between them (methods) because the group of enterprises may include controlled enterprises, which are integrated using global method, joint-ventures, which are subjects for proportionate consolidation and also associates, integrated by equity method ${ }^{3}$.

Therefore, in the case of groups with a complex structure, the methods and the techniques coexist and work simultaneously, under the rules relating them.

Next, we present some characteristics of two techniques, which came out for practice, levels consolidation technique and direct consolidation technique.

\section{Levels consolidation}

Levels consolidation is a steps consolidation, each step finalizing with the preparation of subgroup's consolidated financial statements. A level concentrates all the subgroups from the same consolidation step. Initially, the subgroup joins the entities placed farthest from the parent, regarding the control chain, and the entities next to them. Thus, the subgroups form successively up to the parent where is ending the consolidations' suite with the consolidated financial statements of the group as a whole. In every single subgroup exits an entity, at the superior level, that have a parent role for the other (the others) entity (entities) from the inferior level.

Therefore, figure no. 2, above, first of all will be consolidated the enterprises D and E in their parents $\mathrm{A}$ and $\mathrm{B}$, forming the subgroups $\mathrm{AD}$ and $\mathrm{BE}$, and the next, will be consolidated these subgroups and the entity $\mathrm{C}$ in the parent $\mathrm{M}$.

For the preparation of the subgroups' consolidated financial statements, it is used the parent-role entity's share in every other entity of the subgroup, and for establish the consolidation method it is used the power of the voting rights owned by the group's parent in each consolidated enterprise.

\section{Direct consolidation}

${ }^{2}$ O.M.F.P. nr. 3.055/2009 pentru aprobarea reglementărilor contabile conforme cu directivele europene publicat în Monitorul Oficial nr. 766 din 10 noiembrie 2009

${ }^{3}$ Scorțescu F. I. (2005), Unele considerente cu privire la tehnica de consolidare pe paliere a societăţilor comerciale cu profil horticol, în „Lucrări ştiinţifice”, Universitatea de Ştiinţe Agricole şi Medicină Veterinară „Ion Ionescu de la Brad” Iaşi, vol. 48, seria Horticultură 
Direct consolidation presumes the consolidation of each group's enterprise directly into parent, in this way preparing only the consolidated financial statements of the group as a whole. Thus, it is imperative to share the equity of each consolidated entity between its parent and minority interests according to them portion of investments. Also, between them, must be shared the investments that will be eliminated from consolidation. The instrument used in this case is interests' portion of both, parent and minority interests, but in the enterprise that holds the investments. These two portions are different.

In the case of above example (fig. no.2), the entities A, B, C, D and E will be consolidated directly into parent $\mathrm{M}$, apart from the latent subgroups. The share of their equity will be made using the interests' portion of the parent and minority interests in these entities. For eliminate the investments will be used also their interests' portion but held in A and B.

\section{Levels consolidation vs. direct consolidation}

The both consolidation techniques have special characteristics that will be presented comparatively in below table (table no. 1), emphasizing similarities and differences between them, advantages and disadvantages also.

Table no. 1 Levels consolidation vs. direct consolidation

\begin{tabular}{|c|c|c|}
\hline $\begin{array}{c}\text { Characterization } \\
\text { criteria }\end{array}$ & Levels consolidation & Direct consolidation \\
\hline 1. Goal & $\begin{array}{l}\text { Preparation of the annual } \\
\text { consolidated financial } \\
\text { statements of a group as a } \\
\text { whole; }\end{array}$ & $\begin{array}{l}\text { Preparation of the annual } \\
\text { consolidated financial } \\
\text { statements of a group as a } \\
\text { whole; }\end{array}$ \\
\hline $\begin{array}{l}\text { 2. Applicability } \\
\text { field }\end{array}$ & $\begin{array}{l}\text { Medium and small groups of } \\
\text { enterprises with a complex } \\
\text { structure and a limited levels } \\
\text { of boundaries; }\end{array}$ & $\begin{array}{l}\text { Medium and small groups of } \\
\text { enterprises with a complex } \\
\text { structure and at least two } \\
\text { levels of boundaries; }\end{array}$ \\
\hline 3. Procedure & $\begin{array}{l}\text { On steps, corresponding to } \\
\text { the existent levels of } \\
\text { boundaries in the group's } \\
\text { organigram, into where it is } \\
\text { forming subgroups; }\end{array}$ & $\begin{array}{l}\text { Directly, whatever the number } \\
\text { of the existent levels of } \\
\text { boundaries in the group's } \\
\text { organigram, ignoring the } \\
\text { consolidation steps; }\end{array}$ \\
\hline 4. Principles & $\begin{array}{l}\text { The series of consolidations } \\
\text { start from the entity placed } \\
\text { farthest from the parent, } \\
\text { regarding the control chain, } \\
\text { and ascend up to it; }\end{array}$ & $\begin{array}{l}\text { The order of consolidations is } \\
\text { insignificant; }\end{array}$ \\
\hline $\begin{array}{l}\text { 5. Accomplish } \\
\text { method }\end{array}$ & $\begin{array}{l}\text { It is preparing the } \\
\text { consolidated financial } \\
\text { statements of each subgroup } \\
\text { formed, using the adequate } \\
\text { consolidation method; }\end{array}$ & $\begin{array}{l}\text { It is preparing only the } \\
\text { consolidated financial } \\
\text { statements of the group of } \\
\text { enterprises as a whole, using } \\
\text { the adequate consolidation } \\
\text { method; }\end{array}$ \\
\hline $\begin{array}{l}\text { 6. Used } \\
\text { instruments }\end{array}$ & $\begin{array}{l}\text { At each step, the interests' } \\
\text { portion of the parent-role } \\
\text { entity owned in every other }\end{array}$ & $\begin{array}{l}\text { The interests' portion of the } \\
\text { parent, owned directly in each } \\
\text { consolidated entity, whatever }\end{array}$ \\
\hline
\end{tabular}




\begin{tabular}{|c|c|c|}
\hline & $\begin{array}{l}\text { subgroup's entity, from the } \\
\text { inferior level; }\end{array}$ & the level; \\
\hline 7. Equity share & $\begin{array}{l}\text { At each subgroup, between } \\
\text { the parent-role entity and the } \\
\text { minority interests (including } \\
\text { here, also, the interests' } \\
\text { share of other consolidated } \\
\text { entities from outside of } \\
\text { subgroup); }\end{array}$ & $\begin{array}{l}\text { At the group as a whole, } \\
\text { between the parent and the } \\
\text { minority interests, according } \\
\text { to them share of interests } \\
\text { owned in consolidated } \\
\text { entities; }\end{array}$ \\
\hline $\begin{array}{l}\text { 8. Investments } \\
\text { share before } \\
\text { eliminated them }\end{array}$ & $\begin{array}{l}\text { At each subgroup, the } \\
\text { sharable investments belong } \\
\text { entirely to the parent-role } \\
\text { entity, as a result of direct } \\
\text { own; }\end{array}$ & $\begin{array}{l}\text { At the group as a whole, in } \\
\text { case of indirect boundaries, } \\
\text { between the parent and the } \\
\text { minority interests, according } \\
\text { to their share of interests } \\
\text { owned in the entities that hold } \\
\text { the investments; }\end{array}$ \\
\hline 9. Advantages & $\begin{array}{l}\text { Allows a segmentation of the } \\
\text { financial information within } \\
\text { the group, by the } \\
\text { preparation, first of all, of } \\
\text { the consolidated financial } \\
\text { statements of the subgroups } \\
\text { and only after, the } \\
\text { consolidated financial } \\
\text { statements of the group as a } \\
\text { whole; }\end{array}$ & $\begin{array}{l}\text { Provides directly, quicker and } \\
\text { with less expenses, the state } \\
\text { of the assets, liabilities, } \\
\text { financial position, income and } \\
\text { losses of any group of entities } \\
\text { and allows a better portion of } \\
\text { the consolidated entities' } \\
\text { equity, between the parent } \\
\text { and minority interests; }\end{array}$ \\
\hline 10. Disadvantages & $\begin{array}{l}\text { Requests much more work } \\
\text { for accomplish the suite of } \\
\text { consolidations, involving } \\
\text { more expenses, and also its } \\
\text { applicability is limited. }\end{array}$ & $\begin{array}{l}\text { It not allows analysis within } \\
\text { the group which may } \\
\text { satisfying the needs of } \\
\text { administration and } \\
\text { information, based on a } \\
\text { segmentation on different } \\
\text { activities, geographical areas } \\
\text { etc. }\end{array}$ \\
\hline
\end{tabular}

Whatever the chosen technique, the consolidated financial statements must be the same.

\section{References:}

1. Deju M. (2008), Contabilitate aprofundată. Concepte, modele, studii de caz, Ed. Alma Mater, Bacău

2. Feleagă N., Ionaşcu I. (1998), Tratat de contabilitate financiară, vol. I-II, Ed. Economicã, București

3. Malciu L. Feleagă N. (2004), Reglementare și practici de consolidare a conturilor: din orele astrale ale Eurepei Contabile, Ed. CECCAR, București

4. Munteanu V., Țurcan A. (1998), Grupurile de societăți - Consolidarea contabilă - Ed. Economică, București

5. Scorțescu F. I. (2005), Unele considerente cu privire la tehnica de consolidare pe paliere a societăţilor comerciale cu profil horticol, în „Lucrări ştiinţifice”, Universitatea de Ştiințe Agricole şi Medicină Veterinară „Ion Ionescu de la Brad” Iaşi, vol. 48, seria Horticultură

6. IAS 27 (2004), Ghid pentru înțelegerea și aplicarea Standardelor Internaționale de Contabilitate, Ed CECCAR, București 
7. Ordinul Ministerului Finanțelor Publice nr. 3.055/2009 pentru aprobarea reglementărilor contabile conforme cu directivele europene publicat în Monitorul Oficial nr. 766 din 10 noiembrie 2009 